Soyer himself was attacked by diarrhoea soon after his arrival at Scutari and it lasted several weeks. In the Crimea he was taken seriously ill in September 1855; this illness lasted several weeks and when nearly well he had a relapse. The accounts given are meagre but they are more in keeping with an attack of typhoid fever. When he returned to Scutari he was again ill with fever and later with dysentery, his illness lasting 3 months. These illnesses took toll of his strength. He never again became strong. In 1858 he brought up some blood and his final illness ended in coma. The actual cause of his death is doubtful but high blood pressure is a possible diagnosis.

Alexis Soyer deserves to be remembered for his great work for the soldiers in the Crimean War.

Cook (1912), Morris (1938), O'Malley (1931) and the files of The Times for 1855 were the chief sources of my information.

\title{
REFERENCES
}

Cook, E. T. (1912). Life of Florence Nightingale. London: Macmillan \& Co. Ltd. Morris, H. (1938). Portrait of a Chef. Cambridge: University Press.

O'Malley, I. B. (I93 I). Florence Nightingale, I820-1856. London: Macmillan \& Co. Ltd.

\section{The human factor in hospital feeding}

By Betty R. Stanton, Dietetic and Nutritional Adviser, King Edward's Hospital Fund for London, 24 London Bridge Street, London, S.E.I

'What's the food like?' This or a similar question invariably crops up in any conversation about hospitals. Little curiosity is displayed about the prime functions of a hospital, i.e. the nursing and medical care, or indeed about the softness of the beds or other matters of general comfort. But we are all interested in food and especially when we are ill.

There is, however, a surprising lack of interest in nutrition. Sporadic and individual interest is apparent but there is no nutrition programme or policy in the hospital service, as there is in the Schools Meals Service. In the latter, both the Ministry of Education and Local Authorities recommend minimum amounts of specific nutrients to be provided by recommended quantities of foods and menus. Yet, already Stevenson \& Bensley (1947) were advocating in the Lancet 'The need for a nutritional programme in hospitals, ... made obvious by the frequency with which weight loss, representing tissue destruction, has been observed after injury and in disease. . . . Recent investigations have shown that this weight loss is due to malnutrition which may seriously interfere with recovery'.

Lack of a nutrition policy may be accounted for partly by the historical development of catering in hospitals and partly by the unique position catering holds, both in the smaller world of the hospital and the larger world of the catering industry. 
The first hospitals were charitable institutions for the sick poor, and the feeding of patients was regarded as an integral part of nursing. Florence Nightingale endorsed the concept, and it became a tradition that nurses should look after patients' food, Matron being responsible for menu planning and, through her staff, for preparation and cooking of meals and their service in dining rooms and wards.

With the outbreak of war in 1939, a number of things occurred which upset the traditional organization. Nurses were in demand for nursing, and extraneous duties for which they were not primarily qualified had to be relinquished. Also, supplies of food became increasingly difficult to obtain and those who could cater fairly successfully under peacetime conditions, found it impossible to do so under wartime rationing. Furthermore, because ration books were surrendered to the hospital it was no longer possible to supplement the prewar frugal diet with eggs, butter, fruit, tea, cheese and other 'luxuries', hence catering services had to be expanded to cover a cooked breakfast and supper in addition to the midday meal.

It was obvious to all connected with hospitals that the mounting difficulties of catering could be solved only by major changes in organization and personnel. Between 1945 and $195^{\circ}$ two important documents were published, both of which made recommendations for re-organizing hospital catering: one was the Second Memorandum on Hospital Diet (King Edward's Hospital Fund for London, 1945) and the other the Ministry of Health's (1950) circular, Hospital Catering. Both documents in essence made the same recommendations, namely that catering should be a separate department, in the charge of a trained caterer, and that preferably the caterer should be a dietitian or, if it were not possible, he should be advised in nutritional matters by a dietitian. In the event, neither caterer-dietitians nor therapeutic dietitians have entered the hospital service in sufficient numbers to influence or to contribute greatly to a nutrition policy. Nor has any strong lead come from the Ministry of Health, since the hospitals were taken over on the appointed day, Io years ago. Rather has each Region and each Group of hospitals decided its own standard, which has been influenced apparently more by financial than by nutritional considerations.

The unique position hospital catering holds may be attributed to the following: (I) unlike in hotels or canteens, at least half the consumers are ill; (2) resident staff and some patients remain in hospital over periods of months or years, and the hospital provides meals 24 hours a day, 365 days a year; (3) although the catering department is a separate entity, a large number of people in other departments are concerned, in some degree, with food production and service; (4) a wide variety of tastes, food habits, religious customs and social groups make up the hospital population.

The last point may be common to many establishments but where, other than in a hospital, would one find such different social grades as consultant physicians, porters, technicians, almoners, ward maids and such different nationalities as Poles, Greeks, Czechs, to say nothing about differences in food habits between orthodox Jews, Catholics, Mohammedans or those of vegetarians.

The human factor in hospital catering may be seen at its most human in the interplay between the various departments which daily touch and cross the catering 
department. In theory catering is separate, in practice it overlaps and interrelates with several others. Even when a caterer is in complete charge, at least five other departments materially and vitally affect the quality, including nutritional value, the quantity and palatability of his meals. These departments are: (a) the Hospital Management Committee which decides on the amount of money to be allocated for catering services; (b) the medical staff who prescribe patients' diets; (c) Matron's department, whose nurses serve all patients' meals; (d) Secretary's department, whose porters transport food trolleys; and (e) Domestic Supervisor's department, whose ward maids and orderlies help to serve meals and are responsible for washing crockery, food containers and so on.

Where the catering officer shares responsibility with others, yet more influences come into play; for example, the supplies officer may buy food and be responsible for its storage, or Matron's staff be responsible for serving food in dining rooms as well as wards. And always there is the consumer, either patient or member of staff, demanding that his personal likes, dislikes, inconsistencies, prejudices and phobias shall be recognized. It is hardly surprising that 'nutrition' disappears in this welter of conflicting ideas!

In the short space available it is impossible to consider all the human hazards which can affect food from the moment it is bought to the time it reaches the consumer's plate, but examples are taken from the caterer's department, from those engaged in food transport and in the service of meals.

\section{Caterer's department}

Menu planning. Menu planning is an art and menus vary from the 'French', through anglicized French to good solid English. For example there may be Pommes frites, French fried or simply chips. They are all the same: i.e. chipped potatoes eaten with fried fish, served usually on Fridays ... . The 'French' menus can be a little misleading and very irritating to one who comes to a meal already frustrated and hungry.

Thus, if Consommé julienne turns out to be water flavoured with meat extract, and Boeuf à la casserole to be pale grey, tough and gristly stew; if sauté potatoes are yesterday's cold potatoes, dried up and fried up; and buttered cabbage is overcooked cabbage swimming in a watery mess of yellow margarine globules; and Glace aux fruits is ice-cream and a couple of canned gooseberries, then it is hardly surprising that staff and patients prefer:

Toad in the hole

Mashed and greens

Stewed fruit and custard.

At least they will not be disappointed and may be pleasantly surprised. There are astonishingly many dishes that must be omitted from the menu because patients and staff will not eat them. Everybody is suspicious of anything 'made-up'; meat and two vegetables are easily recognized and therefore acceptable but anything which is 'done-up' or coated with sauce is immediately suspected as being the day before yesterday's left overs in disguise. Hospital personnel are resistant to new dishes, yet 
persistently grumble about monotony and they dislike strong or characteristic flavours such as those of cooked cheese or curry. The popularity of dishes is also subject to seasonal fluctuations. With the approach of summer every young nurse sees herself glamorous and sylph-like in a new outfit, and another slimming craze is born. From thence on, steamed puddings, pastry and potatoes are taboo although calories are consumed between meals in the form of chocolates, biscuits, sandwiches, and sweetened tea and coffee.

Menu planning for patients is fraught with even more complications. Most are physically ill, and are lying in bed, which means that their appetites may be poor. They, like the staff come from a wide variety of homes with widely differing food habits but, unlike the staff, they have to adjust their food habits at a time when they are ill and not at all ready to experiment with new foods and dishes.

Preparation and cooking. Shortage of trained and experienced cooking staff is now the chief factor impeding further improvements in hospital catering. More and more boys and girls leaving school are taking a catering training in technical and domestic science colleges and, although the supply of trained people is increasing, competition from industry, school meals and commerce is as great as ever. Hospitals can offer few attractions and the disadvantages of long hours and weekend duties deter many entrants. Cooking standards in hospitals are not high, and those of us who have cooked on a large scale appreciate the difficulties of achieving and maintaining a good standard of palatability and appearance in the finished product. Let us consider a simple process such as mashing potatoes; if it is done at home for a small family one adds melted butter and milk and beats the potato to a fine floury consistency, free of lumps. For hundreds, the process is done by machinery and often results in a gooey mass full of black knobs, and minus most of its vitamin $\mathrm{C}$.

Various reasons are suggested for this lessening of palatability when food is cooked in bulk.

Whoever prepares food for a family feels a personal interest in, and usually an affection for, those for whom she cooks. She makes an effort to produce a meal which will please and of which she can be proud, either because she wishes to avoid criticism or hopes to receive praise! In large institutions there is no contact between cooks and consumers, hence the cook has no particular incentive to please. Criticisms are often resented and may lead to even lessened interest and less care in preparation.

The handling of large quantities of food is tiring and physical fatigue leads to lessened accuracy and care: after the first few sacks who cares if the eyes are left in potatoes?

Food cooked in large quantities cannot all be served at the same time, and in being kept hot it loses not only nutrients but some subtle flavours and essences as well. Who does not observe the difference between an apple tart taken fresh and crisp from the oven and one which has been in a hot cupboard for half an hour?

Finally the use of machinery, although saving time and labour, lessens the craftsman's art. The 'feel' of a pudding mix or consistency of pastry on the hands and muscles is lacking when machinery is used. 


\section{Distribution and transport}

There are very few hospitals in which meals can be sent directly from the kitchen to the wards and dining rooms. In some there are heated lifts to the wards or a hatchway to the dining room, but in the majority food has to be served twice, once into containers or trolleys for distribution to the wards or dining rooms and secondly from the containers to the individuals' plates. Distribution of food is usually by heated trolley (large metal hot cupboards on wheels) or, in the absence of lifts, by insulated containers small enough to be carried upstairs. Both trolleys and containers are designed to do a satisfactory job and in skilled hands food is delivered hot and in good condition for service. There are, however, many things which may go wrong.

Hospital porters as a class are recruited from the less intelligent, less dedicated and less well physically developed members of society. The trolleys they have to push, are large, heavy and difficult to manipulate. The journey from kitchen to ward may take as long as $20 \mathrm{~min}$ and the route be along an uneven passage, up ramps, into and out of lifts and sometimes across open ground. Considering all the risks, mishaps are not excessive, but it is a little disconcerting for Sister to find that, during transport, the milk pudding has been shaken into the fish or that the custard has coated itself, mayonnaise like, over the salad.

Because space is limited some food may have to be transported on top of the trolley or on an open shelf a few inches above the ground. In the interests of hygiene the person in charge of the kitchen will see that food is covered with cloths or clean paper. Draughty and uneven corridors soon remove these covers and after one or two abortive attempts to replace them, porters give up the unequal struggle. Many, with a look of weary experience, remove the covers immediately they are clear of the kitchen, and food trolleys may ride in the lifts, cheek by jowl with the dirty linen.

Tickets placed with care to label dishes for special diets are similarly blown away during transport. The porter does his best to replace them accurately, but if three or four are blown out at a time, who can say that the diabetic's raw apple will not do the gastric's ulcer good in the long run?

\section{Service}

It is perhaps in serving food that the human factor is most apparent. 'To patients, meal times are an important and welcome break in the routine of the day, and nurses, consciously or unconsciously realizing this, have established an impressive ritual. Sister reigns supreme at the trolley and her nurses and orderlies glide with quiet purpose taking meals to patients' bedsides. Patients look forward to meals with happy expectancy, but many are robbed of appetite by pain, by drugs, or even by the uninhibited and protracted vomiting of the patient in the next bed. To make meals attractive they must not merely be plated well, but they must be 'sold' which can only be done by an imaginative and sympathetic approach on the part of the nurse or orderly. Sometimes this approach is lacking, as on the occasion when anchovy sauce was offered as an accompaniment to steamed fish. As a dish, steamed fish is lacking in taste, and to add flavour the sauce had been provided. One patient asked the orderly, who was taking the jug of sauce from bed to bed, what it was, 'I dunno' 
says she 'looks like pink blancmange'; obviously no patient in that ward wanted pink blancmange with fish! Another time, some cold tongue and salad were offered for supper. As it was wheeled into the ward, a young medical student bent over, sniffed it very disdainfully and in a loud voice said 'What ghastly stuff'. Almost all the tongue and salad were refused.

If patients were all like experimental rats in cages, to be fed nutrients instead of food, if staff could be given packets of protein, fat and carbohydrates in the right proportion with the necessary dusting of minerals and vitamins, how simple hospital catering would be, but how tremendously boring without the human factor.

\section{REFERENCES}

King Edward's Hospital Fund for London (1945). Second Memorandum on Hospital Diets. London: G. Barber \& Son Ltd.

Ministry of Health (1950). Hospital Catering. Circ. Minist. Hlth, Lond., H.M.C., R.H.B., B.G. I8/50. Stevenson, J. A. F. \& Bensley, E. H. (I 947 ). Lancet, 252, 568.

\section{Some experiences in group nutrition}

By J. J. O'Dwyer, Principal Medical Adviser, Unilever Limited, Unilever House, London, E.C.4

I am very honoured to be asked to speak on such an occasion to such an audience. Twenty-two years spent in the Royal Army Medical Corps kept me in mind of the debt we owe to Alexis Soyer, whose centenary we celebrate, and I feel I must express my gratitude for the delightful, thoughtful and fascinating historical background given to us by Mr Le Gros Clark (1959) and Sir Zachary Cope (1959), doyen of medical historians.

It should be realized that I am not speaking as one skilled in the science of nutrition, but merely as a doctor who over the years has been brought face to face with gross problems of malnutrition, which even my untutored eyes would not miss. What follows are some reminisences which may, through knowledge of things seen in the past, help us to keep in perspective the problems of today.

My father was a dispensary doctor in the county of Tipperary and he made me aware of the nutritional problems of farm labourers' children between the years 1912 and 1914 . The area in which he worked, and in which we lived, was a land of rich, heavy soil, a country of numbers of small holdings and some large ones, mostly given over to dairy farming. Milk and butter were poor in quality, herds were of mixed breeds and tuberculosis-ridden, wages were low, profits poor. Every pint of cow's milk sold was important to a farmer, so accustomed by meagre times to extreme frugality that no cow's milk could be spared in many instances even for the farm labourer's small children-hence my father's anger with the times and his own people, the farmers included. Meat, butcher's meat, was only available to the comparatively well-off townsman or tenant or land-owning farmer; others were able 